района Уральской области по Открытому листу, выданному Институтом истории, археологии и этнографии им. Ч.Ч. Валиханова (от 24.06.91 г.). Оренбург, 1991. Рукопись. Фонды Института археологии им. А.Х. Маргулана. № 2362. Оп. 2.30 c.

9. Мамиров Т.Б., Баиров Н.М., Клышев Е.Е., Мамиров К.Б., Куандык С.Р. Полевые исследования каменного века в Западно-Казахстанской области в 2018 году (предварительное сообщение) // Археология Казахстана. 2019. № 1 (3). С. 91-98.

10. Юдин А.И., Выборнов А.А., Васильев И.Н., Косинцев П.А., Кулькова М.А., Гослар Т., Филипп- сен Б., Барацков А.В. Неолитическая стоянка Алгай в Нижнем Поволжье // Самарский научный вестник. 2016. № 3 (16). С. 61-68.

11. Васильев И.Б., Выборнов А.А., Козин Е.В. Исследования неолитической стоянки Каир-Шак 3 // Неолит и энеолит Северного Прикаспия: Межвузовский сборник научных трудов. Куйбышев: Куйбышевск. гос. пед. ин-т, 1989. С. 18-45.

Статья публикуется при поддержкке гранта ИРН АР05134087 КН МОН РК «Каменный век Северо-Восточного Прикаспия».

\title{
THE SITE VAVILINO 1 ON THE RIGHT BANK OF THE DERKUL RIVER IN WESTERN KAZAKHSTAN (MATERIALS OF 2018)
}

(C) 2019

Mamirov Talgat Basarbaevich, candidate of historical sciences, director

Branch of the A.Kh. Margulan Institute of Archeology in Nur-Sultan (Nur-Sultan, Republic of Kazakhstan)

Abstract. The paper is devoted to preliminary data from a study of the Vavilino 1 site in Western Kazakhstan. The monument was first opened by N.M. Malov in 1986, later he picked artifacts from the surface in 1988. In 1991 N.L. Morgunova carried out excavations on the site, which showed the importance of this monument study to understand the Neolithic Volga-Ural interfluve. The monument is located on the right bank of the Derkul River and is currently classified as an emergency. In 2018, employees of the Institute of Archeology named after A.Kh. Margulan in the framework of the Stone Age study in Western Kazakhstan started to work on the monuments of Yeshkitau, Derkul 1 and Vavilino 1. At the Vavilino 1 site a small excavation area - 16 square meters was made, more than a thousand stone artifacts were received; fragments of ceramics and bone remains of animals were poorly diagnosed. Excavations have shown the presence of a $15-20 \mathrm{~cm}$ thick cultural layer belonging to the Neolithic time. The upper layer of the monument with a capacity of up to $30 \mathrm{~cm}$ was destroyed by anthropogenic activities in the past century. The material from the cultural layer is not numerous; tip scrapers, fragments of plates with retouching, geometrical microliths, prismatic nucleus for plates, etc. are typologically distinguished.

Keywords: Western Kazakhstan; Derkul; Volga-Ural interfluve; Holocene; Stone Age; Neolithic; excavation; cultural layer; horizon; profile; artifacts; stone tools; siliceous rock; quartz sandstone; geometric microliths; scrapers; plates; nucleus; retouch; ceramics; bone remains.

\section{НОВОЕ САРМАТСКОЕ ПОГРЕБЕНИЕ НА ЛЕВОБЕРЕЖЬЕ НИЖНЕГО ДНЕСТРА}

(C) 2019

Симоненко Сергей Олегович, научный сотрудник научно-исследовательской лаборатории археологии Приднестровский государственный университет им. Т.Г. Шевченко (2. Тирасполь, Приднестровская Молдавская Республика)

Аннотачия. В 2018 г. в ходе исследования курганной группы «Сад» у с. Глиное Слободзейского района на левобережье Нижнего Днестра в скифской насыпи было обнаружено впускное сарматское погребение с выразительным инвентарём: лепным горшком, гончарным кувшином, серебряной серьгой, ожерельем из пронизей и бусин. Ориентировка погребённого головой на юг-юго-восток достаточно редка в СевероЗападном Причерноморье. С культом огня связаны находки трёх обожжённых галек слева в изголовье. Лепной горшок сочетает в себе черты, известные для посуды данного культурно-хронологического периода. При этом волнообразный орнамент в верхней части тулова зафиксирован только единожды на аналогичном сосуде в Дунай-Днестровском междуречье. Особый интерес представляет гончарный кувшин из комплекса. Подобный формы ранее не были известны в Северо-Западном Причерноморье. Ближайшие аналогии сосуду происходят из памятников Волго-Донского междуречья. Серьги, идентичные найденной в публикуемом захоронении, широко представлены в материалах Прутско-Днестровского междуречья, Среднего и Нижнего Поднестровья. Различные по форме пронизи и бусины ожерелья относятся к наиболее массовому материалу, поступавшему к сарматам из античных центров. На основании анализа погребального инвентаря погребение датируется II в.

Ключевые слова: Нижнее Поднестровье; Прутско-Днестровское междуречье; II век; впускное сарматское захоронение; детское погребение; ориентировка в южном полукруге; культ огня; лепной горшок; гончарный кувшин; Волго-Донское междуречье; серебряная серьга; ожерелье; пронизи; бусины; обожжённые гальки. 
В 2018 г. сотрудниками научно-исследовательской лаборатории археологии Приднестровского государственного университета им. Т.Г. Шевченко были продолжены исследования курганов на левобережье Нижнего Днестра. В курганной группе «Сад», расположенной в 2,6 км к северо-западу от северной оконечности с. Глиное Слободзейского района, были изучены четыре насыпи (№№ 11-14). В кургане 12, помимо основного скифского и впускного средневекового, было обнаружено впускное сарматское захоронение, публикации и анализу которого посвящена настоящая работа.

Насыпь диаметром 15 м к моменту исследований была полностью уничтожена распашкой, её высота от современной поверхности составляла 0,29 м. Курган копался параллельными траншеями с использованием техники. Была разбита бровка по линии север-юг шириной 0,6 м, длиной 22 м (рис. 1).

Погребение 1 (сарматское, впускное) обнаружено в 9,5 м на запад от $\mathrm{R}_{0}$, захоронение перерезало оконечность южной дуги кольцевого рва.
Погребальная яма вытянутой овальной формы размерами 1,42 × 0,53 м. Дно ямы зафиксировано на глубине 1,15 м от $\mathrm{R}_{0}$. Заполнение состояло преимущественно из чернозёма.

На дне ямы, ближе к её восточной стенке, лежал костяк ребёнка 6-8 лет [1, p. 4] в вытянутом положении на спине, головой на юго-юго-восток. Правая рука вытянута вдоль тела, левая согнута в локте и кистью уложена на таз (рис. 1: 2).

Состав и расположение инвентаря. Вплотную к черепу, слева от него, стоял лепной сосуд (1). Севернее, поверх левого плеча, был поставлен гончарный сероглиняный кувшин (2). Южнее лепного сосуда лежала обожжённая галька; ещё две обожжённые гальки (3-5) были найдены у юго-западного угла ямы. Под черепом у правого виска лежала серебряная серьга (6). В районе шеи зафиксировано ожерелье (7). Следов подстилки не обнаружено.

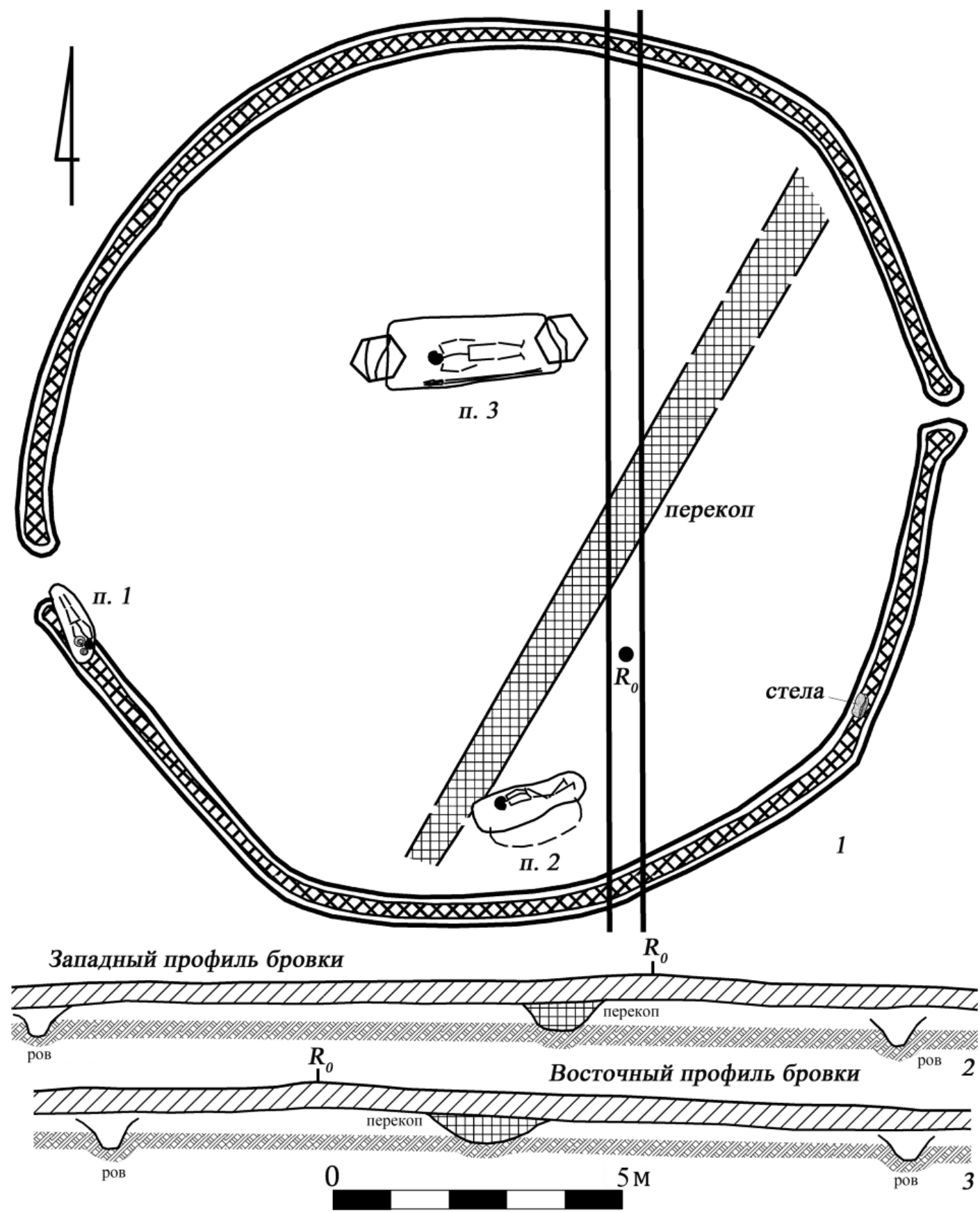

Рисунок 1 - Курган 12 группы «Сад» у с. Глиное Слободзейского района: общий план (1), профили бровок (2-3) 


\section{Описание находок}

1. Лепной сероглиняный горшок с воронковидным горлом, выпуклыми боками и плоским, слегка вогнутым к центру дном. Венчик скошен и орнаментирован косыми насечками. На плечиках четыре вертикальных налепа. Горло отделено от тулова двойной вдавленной канавкой, аналогичная тройная канавка проходит по широкой части тулова. Между указанными канавками прочерчен волнообразный орнамент, представляющий собой тройную непрерывную канавку. Высота сосуда 13 см, диаметр венчика $11,5 \mathrm{~cm}$, тулова $11,7 \mathrm{~cm}$, дна $7,8 \mathrm{~cm}$, размеры налепов $1 \times 1,8 \times 1,2$ см (рис. 2: 3).

2. Гончарный сероглиняный кувшин с биконическим туловом и высоким раструбовидным горлом. Тулово отделено от горла небольшим валиком. Дно вогнутое. Ручка лентовидная, Г-образная, подпрямоугольная в сечении, начинающаяся от верхней части горла и упирающаяся в верхнюю часть тулова с плавным расширением в обеих частях. Высота кувшина $19,8 \mathrm{~cm}$, диаметр венчика $10,5 \mathrm{~cm}$, тулова $17,2 \mathrm{~cm}$, дна $8 \mathrm{~cm}$, размеры сечения ручки до $2 \times 1,4$ см (рис. $2: 4$ ).

3. Обожжённая галька трапециевидной формы, овальная в сечении. Размеры 5,8 × 4,9 см, максимальная высота 2,2 см. На нижней, плоской части гальки имеются следы сработанности (рис. 2: 5).

4. Обожжённая галька округлой формы, трапециевидная в сечении с закругленными углами. Часть гальки отбита. Размеры $3,7 \times 4,7$ см, максимальная высота 2,3 см. На максимально широкой части гальки имеются следы сработанности (рис. 2: 6).

5. Обожжённая галька овальной формы, округлая в сечении. Размеры $3,8 \times 4,8$ см, максимальная высота 3,4 см. На нижней, плоской части гальки имеются следы сработанности (рис. 2: 7).

6. Серебряная серьга неправильной округлой формы, в один оборот. Замок выполнен в виде петли с одной стороны и в виде крючка с другой. Изготовлена из круглой в сечении проволоки. Диаметр серьги 1,1 см, диаметр проволоки 0,1 см (рис. 2: 2).

7. Ожерелье состояло из 52 пронизей и бусин (рис. 3):

- 12 пронизей вытянутой цилиндрической формы из стеклянной пасты оранжевого цвета. Длина пронизей $1-1,5 \mathrm{~cm}$, диаметр $0,4-0,6 \mathrm{~cm}$, диаметр отверстий $0,1-0,15$ см (рис. $3: 1$ );

- 22 зональные (от двух до пяти) бусины из стеклянной пасты синего цвета. Длина бусин 1,2-0,4 см, диаметр 0,4-0,5 cм, ширина «зоны» - около 0,2 cм, диаметр отверстия 0,1 см (рис. 3: 2);

- одна двухчастная (грибовидная?) бусина из стеклянной пасты жёлтого цвета. Длина бусины 0,8 см, диаметр 0,5 см, диаметр отверстия 0,15 см (рис. 3: 3);

- 17 округлых и уплощённых бусин из стеклянной пасты жёлто-зелёного цвета. Высота бусин 0,4$0,25 \mathrm{~cm}$, диаметр 0,4-0,5 см, диаметр отверстий 0,15 0,2 см (рис. 3: 4).

Предваряя анализ погребального обряда и инвентаря, необходимо заметить, что погребение 12/1 группы «Сад» входит в малочисленную группу исследованных курганных сарматских захоронений левобережья Нижнего Днестра.

В Прутско-Днестровском междуречье, по имеющимся в настоящее время данным, впускные сарматские захоронения в курганных комплексах (33\% от общего числа) находятся по распространённости на втором месте после грунтовых погребений (53\% от общего числа). В свою очередь, наиболее малочисленными являются основные курганные погребения $(14 \%)$ [2, с. 26]. На всей территории Северного Причерноморья общее количество впускных сарматских погребений также превышает количество основных [3, с. 177-178].

Погребальное сооружение (яма) вытянутой овальной формы относится к самому распространённому в Северо-Западном Причерноморье типу грунтовых могил (54,6\% от известных погребений) [2, с. 31].

Расположение впускного погребения в западной поле кургана (5,7\%), а также юго-юго-восточная ориентировка $(2,7 \%)$ являются крайне редкими [2, с. 28,33$]$.

Положение погребённого на спине, с прямыми ногами является наиболее распространённым среди сарматских захоронений и в Прутско-Днестровском междуречье. Согнутая в локте левая рука с уложенной на таз кистью также является одним из распространённых признаков позы погребённого [2, с. 33].

Проведённый Н.Е. Берлизовым анализ возрастного различия в обрядности савромато-сарматской культуры позволил установить, что «детские-подростковые» погребения, независимо от пола, преимущественно лежат вытянуто на спине, при этом ориентировка погребений может быть совершенно произвольной. Погребальный инвентарь разнообразен, но чаще всего встречаются один-два сосуда $[4$, с. 255 258]. В свою очередь, А.И. Мелюкова отмечает, что в рядовых захоронениях наборы вещей стандартны и сравнительно немногочисленны. У детей это обычно сосуды, бусы и другие украшения [3, с. 180].

Среди прочих элементов погребального обряда, на которые необходимо обратить внимание, относится помещение в погребение галек со следами пребывания в огне. Данный признак, нашедший отражение и в античных письменных источниках [5, с. 155], и в археологических материалах [5, с. 156-158], является одним из характерных для сарматов.

Лепной сероглиняный горшок с воронковидным горлом, выпуклыми боками и плоским, слегка вогнутым к центру дном из публикуемого комплекса принадлежит к типу сосудов, получивших широкое распространение на территории Прутско-Днестровского междуречья, а также на территории Нижнего Поднестровья. Общим признаком для данных сосудов является форма, орнаментация венчика, а также боковые налепы. Исключением является орнаментация сосуда. Не на всех экземплярах присутствует канавки, очерчивающие границу между туловом и венчиком, и ещё реже встречается волнообразный орнамент, представленный теми же параллельными канавками. Все подобные сосуды происходят из комплексов, вписывающихся в хронологические рамки от второй четверти II в. до начала III в. Морфологически близкие сосуды известны в следующих захоронениях: 1 и 3 Петрештского могильника на левобережье Прута [6, с. 2, рис. 29: 3; с. 4, рис. 31: 3]; курган 8 конца II-III в. у ст. Дзинилор на левобережье Нижнего Дуная [7, с. 36, рис. 11: 10]; 28/1 могильника Алкалия у с. Широкое Белгород-Днестровского района Одесской области в Дунай-Днестровском междуречье [8, с. 15-16, рис. 9: 7]; 5/3 (второй половины II - начала III в. н.э.) у с. Подойма Каменского района на левобережье Среднего Днестра [9, c. 122, рис. 6: 5]; жилища первой половины II-III в. в Танаисе [7, с. 36,38 , рис. $11: 10]$ в Нижнем Подонье. 

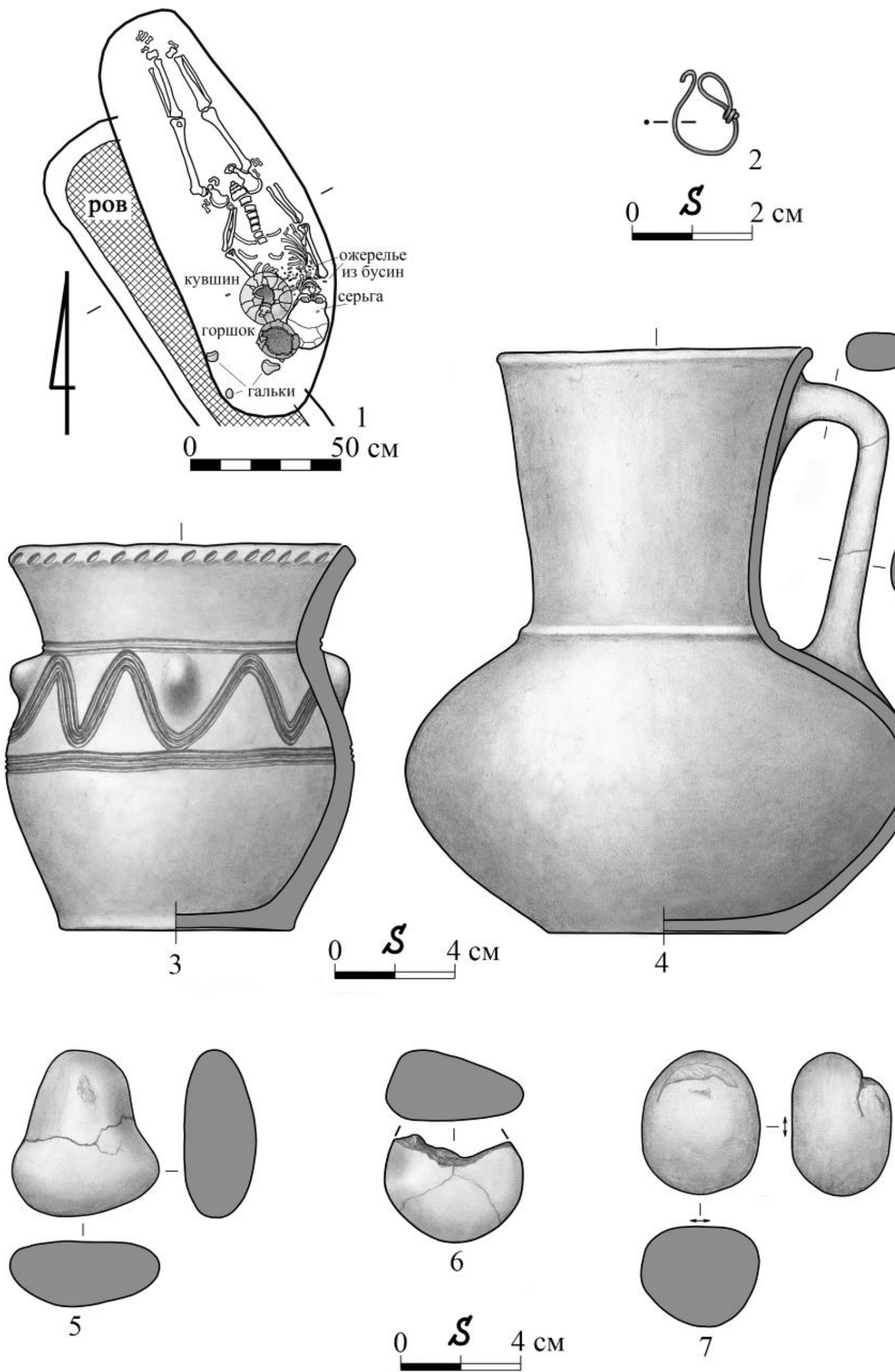

Рисунок 2 - Сарматское погребение 1 кургана 12 группы «Сад» (1), серьга (2), лепной горшок (3), гончарный кувшин (4), гальки (5-7) 

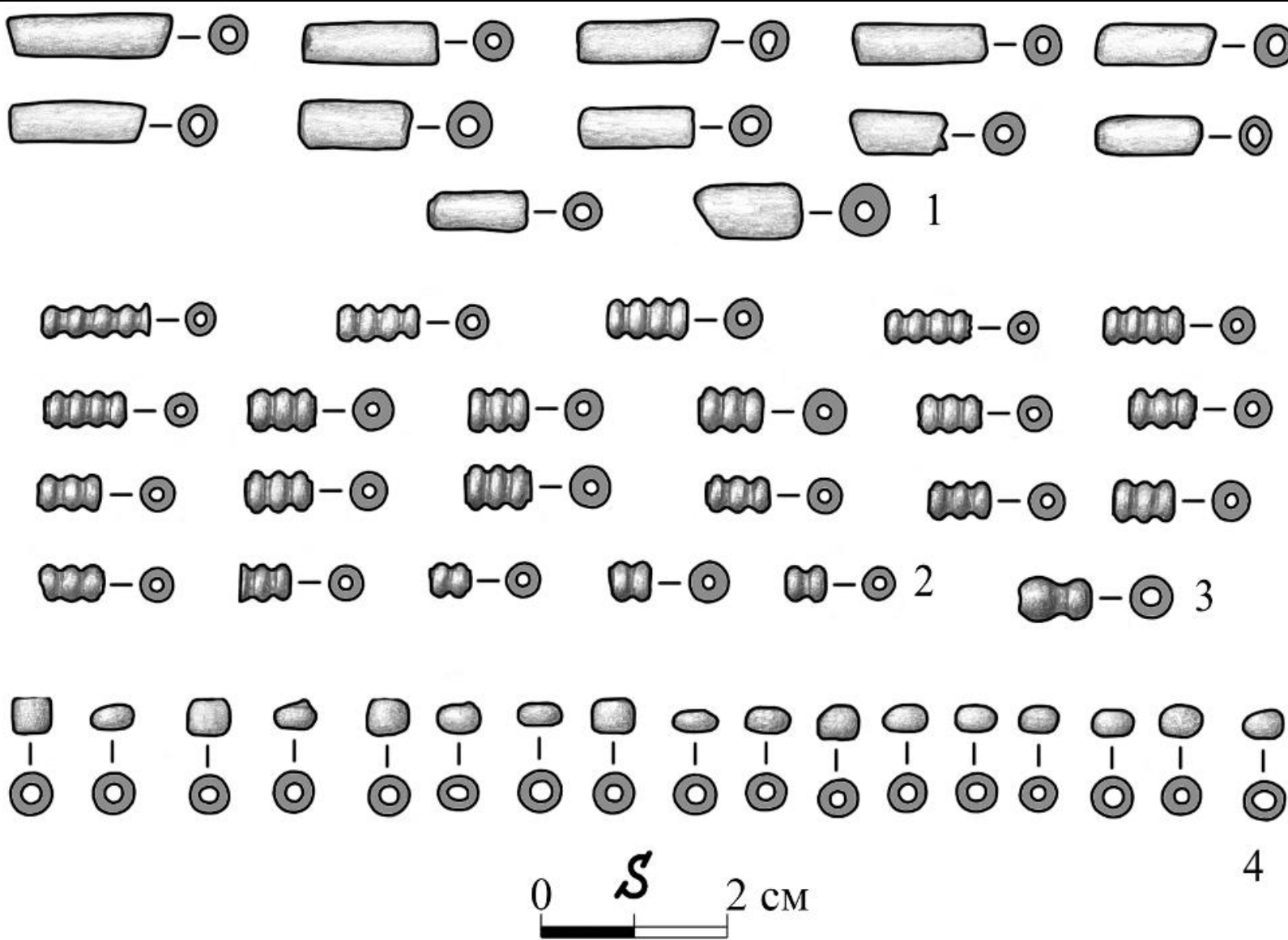

Рисунок 3 - Ожерелье: пронизи (1), зональные бусины (2), двухчастная бусина (3), округлые и уплощённые бусины (4)

Волнообразному орнаменту на лепном сосуде из захоронения 12/1 группы «Сад» известна только одна аналогия - на горшке из сарматского погребения 1/17 могильника Кубей в Дунай-Днестровском междуречье. Комплекс датируется второй половиной II первой половиной III в [10, с. 22, рис. 20: 15].

Аналогии гончарному сероглиняному кувшину из погребения Глиное/Сад 12/1 в Северо-Западном Причерноморье не известны. Подобные кувшины с одной ручкой, биконическим туловом и высоким, раструбовидным горлом встречаются в Волго-Донском междуречье. Они отнесены Р.С. Берестневым к 3 типу [11, с. 57 , рис. 3: 6], датируемому I-II вв. Ближайшие аналогии публикуемому сосуду происходят из кургана 14 у с. Третьяки [11, с. 57, рис. 3: 6] и из комплексов 18/44 и 11/14 Чертовицкого могильника [12, рис. 38: 1-2]. Подобные кувшины поступали на северо-восток Волго-Донского междуречья из различных производственных центров Нижнего Дона и Прикубанья. Близкие им аналогии известны на памятниках I-II вв. Нижнего Поволжья [13, с. 299, рис. 35: 5] и лесостепного Подонья [14, с. 98, рис. $3: 1-2]$.

Серебряная серьга неправильной округлой формы из погребения Глиное/Сад 12/1 имеет замок в виде петли. Подобные украшения часто встречаются в сарматских захоронениях Молдавии и за ее пределами [15, с. 81]. Например, в Среднем Поднестровье близкая по форме бронзовая серьга происходит из погребения 5/1 у с. Подойма Каменского района. Захоронение датируется второй половиной I - началом II в. [9, с. 114, рис. 3: 2]. Кроме того, аналогичные серьги обнаружены в погребениях 4, 6, 8 грунтового могильника Боканы [16, табл. 40: 4, табл. 41: 2, табл. 43: 1] и в погребении 15 могильника Петрешты
[6, с. 21, рис. 40: 5] на левобережье Прута, впускном погребении $1 / 24$ у с. Паланка в Бельцкой степи [17, c. 21, рис. 9: 3], и во впускном погребении 1/11 у c. Ханкауцы Единецкого р-на на левобережье Среднего Прута, в могильниках Старые Куконешты I (погр. 1) и Старые Куконешты II (пятно 10, 24 и 29) [18, рис. $32: 4$, рис. $36: 7$, рис. $38: 11$, рис. $39: 9,10]$, датируемых I-II вв.

Ожерелье, состоявшее из различных по форме пронизей и бусин, относится к наиболее массовому материалу, поступавшему к сарматам в основном из античных центров. По классификации Е.М. Алексеевой, пронизи и бусины из анализируемого погребения относятся к $5,10,15$ и 62 типам, бытовавшим в I-II вв. [19, с. 63, 64-65, 67, табл. 33].

С учётом имеющихся данных о погребальном обряде и аналогий инвентарю из захоронения Глиное/Сад 12/1 можно заключить, что данное погребение было совершено во II в. н.э.

Особого внимания заслуживает то, что на левобережье Нижнего Днестра известные курганные сарматские погребения весьма малочисленны, при этом их погребальный обряд и сопровождающий инвентарь довольно разнообразен. Несмотря на это, ближайшими в хронологическом плане к рассматриваемому погребению являются: впускное захоронение 3/31 (I-II вв.) у г. Тирасполь [2, с. 63], захоронение (основное под насыпью) Чобручи 1/1 (II-III вв.) Слободзейского района на левобережье Нижнего Днестра [20], а также курган 1 (вторая половина II в.) группы «Спутник», исследованный в 2014 г. близ г. Тирасполь [21, с. 101-115], впускные захоронения $2 / 1$ и $38 / 2$ у с. Глиное [22, с. 75,263$].$ 
Принимая во внимание, что впускное детское сарматское погребение является единственным в исследуемой группы «Сад» и только третьим в окрестностях с. Глиное, с большей долей вероятности можно констатировать, что данное захоронение было совершено сарматами на пути их продвижения на запад по территории Нижнего Поднестровья.

\section{Список литературы:}

1. Łukasik S. Anthropological analysis of human skeletal remains from Glinoe SAD site, Moldova: barrows 11-14. Poznań, 10 January 2019. Report submitted to the Taras Shevchenko University in Tiraspol. 2019. 6 p.

2. Гросу В.И. Хронология памятников сарматской культуры Днестровско-Прутского междуречья / отв. ред. М.Б. Щукин. Кишинев: Штиинца, 1990. 202 с.

3. Степи Северного Причерноморья в скифосарматское время. Серия «Археология СССР»/ отв. ред. А.И. Мелюкова. М.: Наука, 1989. 464 с.

4. Берлизов Н.Е. Отражение возрастной стратификации савромато-сарматских племен эпохи раннего железа в погребальной обрядности // Теория и практика общественного развития. Краснодар: ХОРС, 2011. № 2. С. 255-258.

5. Смирнов К.Ф. Сарматы-огнепоклонники // Археология Северной и Центральной Азии. Новосибирск: Наука, 1975. С. 155-159.

6. Яровой Е.В. Отчёт о полевых исследованиях Прутской новостроечной археологической экспедиции в 1986 г. Кишинев 1987 // Архив Национального музея истории Молдовы. № 252 «а».

7. Гудкова А.В., Фокеев М.М. Земледельцы и кочевники в низовьях Дуная I-IV вв. н.э. Киев: Наукова думка, 1984. 164 с.

8. Субботин Л.В., Дзиговский А.Н. Сарматские древности Днестро-Дунайского междуречья. Курганные могильники Алкалия и Хаджидер. Киев: АН УССР, Ин-т археологии, 1990. 48 с.

9. Хахеу В.П., Бубулич В.Г. Исследование курганов в Каменском районе на левобережье Среднего Днестра // Северное Причерноморье: от энеолита к античности (сб. науч. статей) / отв. ред. Н.А. Кетрару. Тирасполь: Типар, 2002. С. 112-148.

10. Субботин Л.В., Дзиговский А.Н. Сарматские древности Днестро-Дунайского междуречья. Курган- ные могильники Васильевский и Кубей. Киев: АН УССР, Ин-т археологии, 1990. 48 с.

11. Берестнев Р.С. Сарматы в междуречье Хопра и Волги: дис. ... канд. ист. наук. Воронеж, 2017. $323 \mathrm{c}$.

12. Медведев А.П. Сарматы в верховьях Танаиса. M.: Tayc, 2008. 218 c.

13. Смирнов К.Ф. Курганы у сел Иловатка и Политотдельское Сталинградской обл. // Древности Нижнего Поволжья. Материалы и исследования по археологии СССР. Т. 1, № 60. М., 1959. С. 206-322.

14. Медведев А.П. Керамика сарматского времени лесостепного Подонья // Археологические памятники эпохи железа Восточноевропейской лесостепи. Воронеж: Издательство Воронежского университета, 1987. C. 93-111.

15. Гросу В.И. Сарматские памятники Среднего Попрутья // Археологические исследования в Молдавии в 1983 г. Кишинев: Штиинца. 1988. С. 79-91.

16. Федоров Г.Б. Население Пруто-Днестровского междуречья в I тысячелетии н.э. // Материалы и исследования по археологии СССР. М.: АН СССР, 1960, № $89.380 \mathrm{c}$.

17. Курчатов С.И. Отчёт о результатах археологических исследованиях курганов близ сёл Паланка и Новые Шальвиры Дрокиевского района ССРМ в 1990 году. Кишинев 1991 г. // Архив Национального музея истории Молдовы. № 318.

18. Дергачев В.А. Материалы раскопок археологической экспедиции на среднем Пруте (19751976 гг.), Кишинев: Штиинца. 1982. 40 с.

19. Алексеева Е.М. Античные бусы Северного Причерноморья // Свод археологических источников. М.: Наука, 1978. Вып. Г1-12. 120 с.

20. Фидельский С.А. Сарматский курган у с. Чобручи на Нижнем Днестре // Старожитності степового Причорномор'я і Криму. Т. IX. Запоріжжя, 2004. C. 272-277.

21. Синика В.С., Разумов С.Н., Лысенко С.Д., Тельнов Н.П. Неординарный сарматский комплекс из окрестностей Тирасполя на левобережье Нижнего Днестра // Stratum plus. 2015. № 4. C. 101-113.

22. Тельнов Н.П., Четвериков И.А., Синика В.С. Скифский могильник III-II вв. до н.э. у с. Глиное (Археологические памятники Приднестровья. III). Тирасполь: Stratum plus, 2016. 1096 с.

\section{NEW SARMATIAN GRAVE ON THE LEFT BANK OF THE LOWER DNIESTER}

(C) 2019

Simonenko Sergey Olegovich, researcher of Scientific Laboratory of Archaeology

Pridnestrovian State University named after of T.G. Shevchenko (Tiraspol, Pridnestrovian Moldavian Republic)

Abstract. In 2018, a secondary Sarmatian burial with an impressive inventory (molded pot, pottery jug, silver earring, necklace of beads) was discovered in the Scythian mound in the course of the study of the barrow group «Garden» near the Glinoe village, Slobodzeya region, on the left bank of the Lower Dniester. Orientation of the buried head to the south-southeast is quite rare in the North-West Black Sea region. The cult of fire is fixed by the finds of three burned pebbles from the left to the head. A handmade pot combines features known for the dishes of a given cultural and chronological period. At the same time, the wave-like ornament in the upper part of the body was fixed only once on a similar vessel in the Danube-Dniester interfluve. Of particular interest is a pottery jug from the complex. Such forms were not previously known in the North-West Black Sea region. The closest analogies to the vessel come from the sites of the Volga-Don interfluve. Earrings identical to those found in the published grave are widely represented in the materials of the Prut-Dniester interfluve, the Middle and Lower Dniester. Necklaces of various shapes and beads belong to the most mass material received by the Sarmatians from ancient centers. The burial dates back to the $2^{\text {nd }}$ century based on the analysis of the grave goods.

Keywords: Lower Dniester region; Prut-Dniester interfluve; $2^{\text {nd }}$ century; secondary Sarmatian burial; child grave; orientation in southern semicircle; rite of fire; handmade pot; pottery jug; Volga-Don interfluve; burnt pebbles; silver earring; necklace; beads; burned pebbles. 